\title{
Finnish Versions of Pragmatist Humanism
}

Eino Kaila and Georg Henrik von Wright as Quasi-Pragmatists

\section{Sami Pihlström}

\section{(2) OpenEdition \\ 1 Journals}

Electronic version

URL: http://journals.openedition.org/ejpap/1543

DOI: $10.4000 /$ ejpap. 1543

ISSN: 2036-4091

Publisher

Associazione Pragma

\section{Electronic reference}

Sami Pihlström, "Finnish Versions of Pragmatist Humanism », European Journal of Pragmatism and American Philosophy [Online], XI-1 | 2019, Online since 19 July 2019, connection on 21 July 2019. URL http://journals.openedition.org/ejpap/1543; DOI : 10.4000/ejpap.1543

This text was automatically generated on 21 July 2019

\section{(c) $($ ) $\odot$ (8)}

Author retains copyright and grants the European Journal of Pragmatism and American Philosophy right of first publication with the work simultaneously licensed under a Creative Commons AttributionNonCommercial-NoDerivatives 4.0 International License. 


\title{
Finnish Versions of Pragmatist Humanism
}

Eino Kaila and Georg Henrik von Wright as Quasi-Pragmatists

\author{
Sami Pihlström
}

\section{AUTHOR'S NOTE}

This is not exactly the paper I presented at the conference on "European Pragmatism" in Vienna in April, 2018, on which this publication is based. At that conference, I discussed Nordic pragmatism (cf. Pihlström 2010). This essay summarizes some of my views on Kaila's and von Wright's relations to pragmatism originally developed in other contexts (see the bibliography for references). In addition to three anonymous reviewers, I am greatly indebted to Martin Kusch, Matthias Neuber, Ilkka Niiniluoto, Mikko Salmela, Friedrich Stadler, and of course the late Georg Henrik von Wright regarding many of the ideas discussed in this essay.

\section{Introduction}

1 As the papers in this collection demonstrate, philosophers active in Europe in the early decades of the twentieth century developed not only insightful and original responses to the American pragmatist tradition but also philosophical ideas not explicitly influenced by the American pragmatists yet bearing striking resemblance to pragmatist thought. Philosophers in the Nordic countries were no exception. Pragmatist themes were discussed early on especially in Denmark, Sweden, and Finland. (For historical examinations of "Nordic pragmatism," see Pihlström 2010; Rydenfelt 2018.) This paper will not trace the general history of Nordic pragmatism reception. I will only examine, as a case study, two major Finnish philosophers, Eino Kaila (1890-1958) and Georg Henrik von Wright (1916-2003), whose contributions to pragmatism were perhaps not obvious and are certainly less known and less frequently acknowledged than their contributions 
to logical empiricism and analytic philosophy - but were nevertheless original and potentially relevant to the on-going re-evaluation of the pragmatist tradition and its European influences and analogies.

Obviously, pragmatism has never been a major current of thought in Finland or any of the other Nordic countries; even so, William James's writings, in particular, were relatively widely read in the 1910s, and some critical discussions continued in the 1920-30s, although after those decades pragmatism was - as in many other places, too - eclipsed by logical empiricism. ${ }^{1}$ Some Finnish thinkers were genuinely interested in pragmatism even in the 1940s and 1950s, when analytic philosophy became overwhelmingly dominant. The grand old man of Finnish analytic philosophy, von Wright, referred to Peirce and James in his introductory book on logical empiricism (von Wright 1943). Oiva Ketonen, who (like von Wright) was Kaila's pupil and who became Kaila's successor as Professor of Theoretical Philosophy at the University of Helsinki, wrote an essay on Dewey after Dewey's death (Ketonen 1954), and his Deweyan naturalism is also visible, for instance, in his popular work on "the world-view of the European man," Eurooppalaisen ihmisen maailmankatsomus (Ketonen 1981 [1961]: chapter 10). However, most Finnish philosophers around that time, and perhaps even more so in the 1970s and 1980s, were presumably relatively unfamiliar with pragmatism. None of the internationally well-established analytic philosophers in Finland - von Wright, Ketonen, Erik Stenius, Jaakko Hintikka, Raimo Tuomela, Ilkka Niiniluoto - can be said to have been a pragmatist, but upon closer inspection it is clear that most if not all of them have been preoccupied with pragmatist or at least quasi-pragmatist themes. ${ }^{2}$

3 The most important figure in the early Finnish reception and development of pragmatism was undoubtedly Eino Kaila. As a young man, Kaila was impressed by James's philosophy and other pragmatist ideas (cf., e.g., Jääskeläinen 1983: 13, 16-8; Niiniluoto 1990: 18). Already in 1911, he wrote an essay on Henri Bergson (Kaila 1911a), whose vitalism and anti-intellectualism had influenced James's late views, and in the same year he published another short paper with references to philosophers close to pragmatism - Bergson, Emil Boutroux, and F.C. S. Schiller (Kaila 1911b). In 1912 he interpreted James's views to the readers of the newspaper Uusi Suometar in a paper to be discussed in some detail shortly. He then reviewed several Finnish translations of James's works (Kaila 1914, 1915, 1916). While Kaila soon turned to other ways of philosophizing and became a kind of external member of the Vienna Circle in the late 1920s and early 1930s, his logical empiricism still contained significant traces of pragmatism, as can be seen by studying his later works (Kaila 1986 [1943], 2014 [1939]). ${ }^{3}$

4 Among Kaila's many students who later became distinguished professors, von Wright stands out as the most eminent figure. The pragmatist dimensions of his thought were much less explicit than Kaila's, though. It would be impossible even to begin to describe von Wright's enormous impact on the development of logic, philosophy of science, theory of action, and many other fields; I will only, after having explored Kaila's pragmatism at some length, provide some remarks on a pragmatist aspect we may perceive in von Wright's views on causation and action (see further Pihlström 2014).

5 I will begin by an exposition of some of Kaila's views relevant to the topic of this paperfirst his early pragmatist writings and then his later discussions of "practical testability" - and subsequently move on to consider von Wright's pragmatist lines of thought. Overall the paper will suggest that these two philosophers and the many others around and succeeding them (not to be discussed here) might be seen as having established a hidden 
tradition of Finnish philosophy: a kind of pragmatist humanism. Their versions of such pragmatism are quite different, however. Whereas Kaila moved from a Jamesian pragmatist humanism concerned with religion and metaphysical Weltanschauungen to logical empiricism and its critique of metaphysics, von Wright's humanist or pragmatist ideas are to be found, for example, in his theory of action and "actionist" theory of causation. As a public philosopher engaged with societal and cultural issues, von Wright was, moreover, closer to Deweyan social humanism than Kaila (without any explicit Deweyan influences, though).

\section{Kaila's Early Pragmatist Influences}

The 1912 article on James is, clearly, the most important among Kaila's early contributions to pragmatism. In this relatively popular essay Kaila emphasizes the significance of James's pragmatism as a new, revolutionary philosophy. James, he claims, has shown us that we are not mere passive spectators of the world but, above all, actors (Kaila 1912: 84). According to Kaila, James's view is a "new answer" to the problem of how someone who does not want to give up reason and rationality, or make any easy intellectual compromises, can still deal with their religious needs, with their hope to reach "higher" spirituality in life, a hope whose satisfaction might be necessary for the happiness of their entire life (ibid:: 81-2). Kaila here endorses James's doctrine of the "Will to Believe" (see James 1979 [1897]: chapter 1): a religious or "idealistic" hypothesis concerning the significance of human life in connection with a more spiritual eternal universe can be accepted through an active, voluntary effort; yet, we have to embrace such beliefs with our own risk, being unable to ever finally "prove" any such hypotheses. Still, according to both James and Kaila, it is better to believe and act on the basis of such an insecure belief than to fall into skeptical or agnostic inactivity. Only thus can life have a deeper meaning and be worth living. (Kaila 1912: 84-6.) The same idea is repeated, for instance, in Kaila's (1917) short biography of Ernest Renan. These early writings demonstrate that Kaila was intensely preoccupied with religious and existential issues, even though his professional academic work focused, at that time, mostly on empirical psychology.

Let me quote Kaila (paraphrasing James) at some length:

All life, therefore, consists essentially in daring, "risking" - life-threatening experiments, in which we expose a great deal of things to risk, and a great deal of things, perchance, will be won by us. Yet, if we do not expose anything to risk, neither will we gain anything; that, for one, is certain.

This primordial wisdom of everyday experience William James has elevated into a philosophical principle, making it one of the cornerstones of his pragmatic philosophy. At the center of each world-view is the question concerning the value of life . [...]

To the question concerning the value of life we must thus respond: this is contingent on the living person. If I tend not to dare anything simply because no one can prove the value of life to me, I surrender myself to doubt, and the victory of skepticism is sure, the world around me pitch-black. Should I dare believe, on the other hand, in the meaning of life even at the risk of error, so life will be luminous at least on this spot, and if death puts an end to it all, I couldn't have faced it better. $\left(\right.$ Kaila 1912: 84) ${ }^{4}$

8 In the same essay, Kaila also discusses, albeit only briefly, James's notorious pragmatist theory of truth, pointing out that while James is sometimes obscure and even 
contradictory, his theory amounts to the thesis that a mere "agreement" of an idea with reality is insufficient as a criterion of truth and that we therefore have to use the "working" of ideas as such a criterion (ibid.: 91). Hence, Kaila joins those, presumably including James himself, who consider the mere correspondence-theoretical "agreement" between a truth and what it is true about empty or trivial while endorsing the correspondence theory as a basically correct general account of truth. This view is, clearly, compatible with a correspondence theory insisting on the distinction between the meaning of truth (correspondence) and the criterion of truth (pragmatic working, usefulness, value, satisfactoriness, etc.), even though a more sophisticated pragmatist account of truth might continue to question the sharpness of this dichotomy between meaning and criterion. In his review of the 1913 Finnish translation of James's Pragmatism , Kaila remarks that the pragmatist theory of truth may remain an "awkward mistake," but goes on to say that all those preoccupied with "ultimate questions" should read James's work (Kaila 1914).

On the whole, Kaila's attitude to James and pragmatism seems to have been very positive throughout most of the 1910s. The pragmatist theory of truth was never his main concern; above all, he was interested, as James also was, in the application of pragmatism to profound weltanschaulichen questions about the significance of human life and the possible role of religion regarding such questions. He was vitally concerned with the question of whether we, being unable to ever reach any certainty about religious conceptions, could nevertheless find some value and direction to our lives. Kaila, then, was never (even in his early thought) a pragmatist in anything like the full sense of the term, but as a reader of the 1912 James essay easily notices, he did substantially contribute to pragmatist examinations of the relation between science and religion, in particular. Moreover, his contribution was not restricted to his early enthusiasm with James; nor did he merely embrace and develop Jamesian pragmatist ideas but made, as we will see, original developments with the pragmatist views he had originally adopted from James.

\section{Kaila's Later Pragmatism: "Practical Testability"}

Turning to Kaila's later thought, let us start from the obvious: as a logical empiricist, Kaila was of course "officially" sharply critical of religion and metaphysics, including the kind of Jamesian-inspired pragmatist philosophy of religion he had defended in the 1910s. Famously, leading logical empiricists like Rudolf Carnap maintained that religious and theological questions concerning, say, theism and atheism were meaningless pseudoproblems, lacking cognitive content. The mature Kaila of the 1930-40s was, in the spirit of the Vienna Circle, primarily a philosopher of science, also introducing modern logical and epistemological ideas in Finland. However, Kaila never abandoned his early Jamesian idea that truth about religious issues and, more generally, metaphysical or weltanschaulichen questions concerning the significance of human life must be assessed from the point of view of practice.

11 As metaphysical and religious statements fail to meet the rigorous criteria of scientific meaningfulness set by the philosophers of the Vienna Circle, Kaila's criticism of metaphysics culminates in the "principle of testability," a variation of Carnap's and other logical empiricists' related principles: any statement about reality must be constructed in such a way that a set of empirical statements (the "real content" of the original 
statement) can be derived from it; the truth or probability of the statement can only be assessed on the grounds of its real content (for detailed formulations, see the essays collected in Kaila 1979). Now, even though metaphysical and religious views are not scientifically acceptable in this sense, they may, as Kaila (1946 [1934]: 365) suggests in his psychological magnus opus on human personality, function as "spiritual insurance companies" defending us against various threats of life, especially the fear of death. Metaphysical and religious conceptions need not be entirely fruitless, as they may still be critically tested and evaluated, albeit only in a practical way.

Accordingly, Kaila argued - pragmatistically, we might say - that religious and metaphysical worldviews may be "practically testable," even if they cannot meet the requirement of empirical testability applied to scientific theories because of their minimal "real content." What Kaila calls practical testability has nothing to do with the real content of beliefs or statements; rather, it focuses on their results in practical action and ways of living. Religious and metaphysical ideas may serve as motives for action, and they may even be endorsed insofar as their practical results are worthwhile (Kaila 1986 [1943]: 188-9). Religions may, then, be acceptable as "systems of action," not as systems of beliefs. Their "practical truth" must, however, be distinguished from "truth in the proper sense," the pursuit of which is the concern of scientific theories (ibid.: 190). Religions and religiosity must, furthermore, be clearly distinguished from each other: religiosity is the "deep-mental" or spiritual core of religions. Mental life, Kaila maintained, is "deepmental" (deeply spiritual) when the depth dimension of an emotion reaches its maximum value, i.e., when the object of the feeling, some value, is perceived as "sacred" (Kaila 1946 [1934]: 364-5; cf. 239).

Taking a somewhat more detailed look at Kaila's richest elaboration of the concept of “deep-mentality," i.e., the book Syvähenkinen elämä (1943, 3rd ed. 1986), it is interesting to note that Kaila there explicitly proposes to apply, "without restrictions, the way of thinking called pragmatism," to metaphysical "explanations of the world," pointing out that pragmatism leads to contradictions when applied to theoretical conceptions of the world but may legitimately be applied to "views of life." Echoes from the early James essay are certainly identifiable here. However, here deep-mentality is not merely an instrument for saving religious and metaphysical views; it seems to become a normative concept to be applied in ethics as well; indeed, deep-mentality or spirituality in this sense is argued to be the most important thing in human life (cf. Niiniluoto 1992a: 19-20). However, the basis of this normative concept lies in our biological nature. Kaila remained a naturalist, though an antireductionist one. From the biological and psychological point of view, deep-mentality belongs, he argues, to the emergent totality of human needs.

The pragmatically most interesting reasoning here proceeds as follows (as already anticipated in the 1934 psychology book cited above). While the "real content" of religion and metaphysics is small, virtually zero, religious and metaphysical Weltanschauungen can, according to Kaila, be significant in a practical sense. "Practical testability" does not assess the real content of a system of beliefs at all, but rather its consequences in our practical actions and the ways the belief system tested is able to satisfy our human needs. Kaila, the son of a Lutheran arch-bishop, did not approve of religions as systems of beliefs, but he did respect them in his own critical manner and maintained that they might be (at least partially) justified as systems of action. Eubulos, one of the fictitious characters and presumably his alter ego in Syvähenkinen elämä, reflects: 
Views of life are testable on the basis of the results they have as motives of action. From their fruits you shall know them. Those views of life are good which have good fruits. For my part, I am inclined to judge metaphysical "explanations of the world" from this perspective. I would apply to them, without restrictions, the way of thinking called pragmatism, which leads to contradictions and other impossibilities, if applied to theoretical conceptions: whatever is good is "true." Some view of life is "true," that is: acceptable, insofar as it leads to acceptable results when followed in practice. But this "practical truth" is of course something else than truth in the proper theoretical sense. (Kaila 1986 [1943]: 189) we consider Kaila's mature work. Both men were - especially in early stages of their careers - psychologists as much as philosophers. Even more strikingly, both were extremely broad in their intellectual profiles, combining scientific perspectives with strong "romantic" sentiments focusing, rather, on art and religion. Indeed, syvähenkinen elämä is explicitly a dialogue between a scientifically-minded and a more romanticallyoriented character with process-metaphysical ideas. In Kaila's case, perhaps more than James's, the scientific "ego" was stronger. However, even in that late work from the 1940s, James's voice can be heard in Aristofilos, the "romantic" and more metaphysical character - as Kaila explicitly admits both in the preface and in the dialogue itself (1986 [1943]: 8, 202). Indeed, Aristofilos points out, as James himself might have done, that theoretical and practical testability may in the end collapse into one another, especially when we are dealing with "theories about the spiritual."

Thus, Kaila's “scientific" alter ego Eubulos is seriously confronted by Aristofilos, whose point of view is also to some extent Kaila's own. It is Eubulos, the scientific-minded clearheaded philosopher representing logical empiricism, who formulates the abovementioned distinction between the two versions of the testability principle and the corresponding distinction between truth in its theoretical and practical sense, but it is Aristofilos, the religiously and aesthetically inclined partner in the dialogue, whose pragmatism is more thoroughgoing. His words could indeed have been written by James himself: ${ }^{7}$

It seems to me that you are making a mistake when you distinguish in a strict and principled way between this "theoretical testability" and the "practical testability" through which the "validity" of views of life is determined. It seems to me, on the contrary, that they are close to each other. [...] When we are dealing with theories about the spiritual, theoretical and practical testability collapse together. (Kaila 1986 [1943]: 192)

18 For example, God may, according to both Kaila's Aristofilos and William James, need our faith as a support of His existence (ibid.: 193). This is a suggestion that the "winner" of the dialogue, Kaila's scientific ego, of course firmly rejects, but one can hardly deny that Kaila was internally tormented by these diverging ideas, perhaps partly as a result of his early admiration of James, a philosopher also tormented by conflicting "temperaments" - and the need to reconcile them. He may have seen the identification of theoretical and practical testability as a temptation of his own philosophical temperament (to employ a Jamesian concept), ${ }^{8}$ a temptation he nevertheless at least mostly succeeded in resisting. The two voices of the dialogue are both genuinely his own, while the scientific one 
ultimately prevails. While Aristofilos is not just an opponent of Kaila's logical-empiricist position expressed by Eubulos but an organic part of Kaila himself, it is Eubulos who won the battle within Kaila - and in Finnish philosophy at large.

\section{Kaila and Jamesian Pragmatism: Further $\mathrm{S}$ imilarities and Differences}

19 Kaila's philosophy, when it comes to "ultimate questions," is very close to James's at least in one significant respect: he is, we may say, a "pluralist" not in the metaphysical sense that would conflict with his monism (cf. von Wright 1992) but in a more metaphilosophical sense manifested in his philosophical methodology, especially in the dialogical work Syvähenkinen elämä. Different voices - the different philosophical temperaments appearing in that book - deserve to be heard, to be carefully listened to, and taken seriously. While a dialogue may in the end be a disguised monologue (see Kaila 1986 [1943]: 7), and thus "monistic," there are sometimes genuinely diverging "voices," e.g., scientific and religious ones, within a single thinker. Developing and maintaining a fundamentally monistic view of the world may be a special challenge for such a person, a challenge that can only be met by engaging in a genuine internal dialogue.

James himself, I believe, would have been happy with the merging of theoretical and practical testability - to the extent that something like their integration could even be regarded as a corner stone of his pragmatism. Moreover, James was characteristically ambivalent between focusing on the (conceivable, potential) practical effects of believing something, on the one side, and focusing on the (conceivable, potential) practical effects that might follow from that belief being true (and he has often been criticized because of this ambivalence). Insofar as there were, in the end, no fundamental difference between theoretical and practical testability - that is, insofar as the pragmatic consequences of one's believing in a certain (e.g., metaphysical or religious) proposition that might come about in one's life played a role in determining the actual content of that proposition and its "truth" in a more literal sense - this ambivalence would be better justified than it would if based on a more conventionally realistic picture of beliefs and their relation to a belief-independent reality. To collapse this difference would be to take extremely seriously the original pragmatist idea of beliefs as "habits of action." It is clear that Kaila never went that far in his admiration of James - not even in his early 1912 essay - and it is unclear whether even James ever embraced pragmatism in such a strong form. However, James's pragmatism (but presumably not Kaila's) can be developed into a conception of ethical values penetrating into the very core of our metaphysical beliefs and postulations (cf. Pihlström 2009). Such developments of pragmatism might be cashed out in terms of Kaila's notions of theoretical and practical testability.

In addition to the fact that Kaila was, thus, in the end more scientifically focused than James, a major philosophical difference between the two is that while James was, famously, a philosophical pluralist, Kaila was always strongly tempted to advance a monistic position and struggled throughout his career to find an adequate philosophical expression for this idea. Since his early "philosophical awakening" as a teenager, he was convinced that the world is a monistic totality (see Kaila 1953; cf. von Wright 1992). At some points of his intellectual development, he may therefore have been close to something like the "neutral monism" advocated by Ernst Mach, Bertrand Russell, and 
others - a position often compared to James's "radical empiricism" - although he opposed, from early on, the "superficiality" of such positivistic forms of monism, their tendency to overlook the highly significant "riddle of reality"; indeed, Kaila never joined the logical positivists in regarding that problem as a pseudo-issue. ${ }^{9}$ Another dimension to Kaila's monism is metaphilosophical: philosophers' dialogues, presumably including his own construction of an imagined dialogue in that book, are often just "monologues in disguise" (Kaila 1986 [1943]: 7).

In any case, Kaila's monism was always non-reductive; ${ }^{10}$ he never accepted reductive mechanical materialists' scientistic views, any more than James did. However, it might also be suggested that the very controversy between monism and pluralism is among those that should, on the basis of Kaila's own principles, in the end be evaluated "tested" - practically, not theoretically. While Kaila himself viewed this controversy as a scientific one, to be settled within "scientific philosophy" - or, possibly, synthetic philosophy of nature based on the most advanced findings of science - I believe we should join James in construing the monism vs. pluralism debate in more pragmatic terms, as a fundamental weltanschaulich issue to be explored in terms of the question concerning our ability of finding ourselves "at home" in the universe.

It is clear that Kaila never became a thoroughgoing pragmatist. As a strict empiricist he was, despite his early admiration of Bergson and James, unable to arrive at the kind of dynamic, active, and holistic concept of experience that may be seen as one corner-stone of pragmatist philosophy. Accordingly, he was never able to build a sustainable bridge between normativity (deep-mentality) and naturalness (its bio-psychological basis), although he sincerely tried.

On the other hand, there is also a touch of pragmatic pluralism in Kaila's suggestion, toward the end of the 1912 James essay, that the "man of action" understands the multilayered structure of reality better than the person who views the world solely from the natural-scientific perspective. For a narrow-sighted scientistic reductionist, Beethoven's string quartet is just something material and physical ("[r]ubbing horse's mane against cat's intestines") (Kaila 1912: 91; again quoted from the 2011 English translation). In contrast, the pragmatist realizes that there are multiple contexts and perspectives of description and inquiry, with their different pragmatic grounds and purposes. The world as a "structured whole" 11 is thus, though monistic in a basic naturalistic sense, not reductively monistic but enormously rich and deep. Within such monism, the conflict between monism and pluralism may in the end vanish, at least as a traditional metaphysical issue, when seen from a pragmatic point of view. ${ }^{12}$

Kaila's non-reductive monism is in some ways even close to panpsychism, refusing to draw any dualistic distinction between mind and matter. "Allt är materia, allt är själ," "Everything is matter, everything is soul," as Kaila (1952) put it in the title of one of his essays written in Swedish. ${ }^{13}$ For a pragmatist, one way of accounting for the different "layers" of reality could be by means of the kind of "relativization of reality" Kaila proposed in his late work. According to Kaila, real objects can be "ordered" in terms of their increasing invariance, which is connected with increasing conceptualization, with theoretical scientific entities as the most conceptualized (and in a sense the most "real") ones..$^{14}$ While this position is neither Kantian nor pragmatist but in an important sense scientifically realist, it might be compared to Hilary Putnam's internal realism, which, in turn, was one of the most important neopragmatist approaches to the realism issue in the late twentieth century. ${ }^{15}$ Kaila's stance to the problem of realism remains ambivalent, but 
his relativizing move might be employed, by a pragmatist at least, in the non-reductive project of acknowledging the (contextualized) reality of both physical, scientifically conceptualized reality and everyday phenomenal experiences - as well as values and other cultural structures and processes. This would take us beyond Kaila's own concerns with the problem of reality, though.

\section{Von Wright on Action and Causation} "manipulative," and "experimentalist," suggesting that the notion of cause is "essentially tied to the idea of action and therefore, as a scientific notion, to the idea of experiment" (von Wright 1971: 36-7; cf. 189-90; see also von Wright 1974: 57). ${ }^{17}$ While admitting that etymology is not decisive here, he also refers to the link between the concepts of cause and guilt captured by the corresponding words in classical languages (as well as Finnish) (von Wright 1971: 64-5). Regardless of etymology, "we cannot understand causation, nor the distinction between nomic connections and accidental uniformities of nature, without resorting to ideas about doing things and intentionally interfering with the course of nature" (ibid.: 65-6). More precisely, the connection between causation and action is spelled out by von Wright as follows: " $p$ is a cause relative to $q$, and $q$ an effect relative to $p$, if and only if by doing $p$ we could bring about $q$ or by suppressing $p$ we could remove $q$ or prevent it from happening" (ibid.: 70). Thus, by manipulating the cause we can, in principle, bring about the effect; this is of course crucial in scientific experimentation.

In a slightly later work, von Wright specifies the theory while connecting it to the issue of determinism. The leading argument is that "[t]he idea that causal connections are necessary connections in nature is rooted in the idea that there are agents who can interfere with the natural course of events" (von Wright 1974: 1-2). In our conceptual order, so to speak, action is the primary concept and causation the secondary one (ibid:: 2). The conclusions he eventually arrives at regarding the determinism vs. indeterminism dispute are not ontological or metaphysical, either, but rather of a conceptual or epistemic nature (see ibid:: 136). Von Wright concludes:

To say that to establish the ontic certainty of a change presupposes an epistemic certainty [...] is but another way of saying that establishing causal bonds in nature presupposes action. It is by virtue of these relationships that I say that the concept of cause presupposes the concept of action. Action, however, cannot rightly be said 
to presuppose the existence of ontic alternatives in nature, i.e. the truth of some form of indeterminism. What action presupposes is only the epistemic certainty which, as long as it is not undermined, entails the belief in the ontic contingency of some changes and thus takes for granted a certain margin of indeterminism in the world. (Ibid.)

This theory of causation, which might be claimed to come somewhat close to the "interventionist" developments in contemporary discussions of causality and explanation (e.g., Woodward 2003), has often been criticized because it appears to make causation "human-centered" in a problematic way. The relations between cause and effect seem to be relative to what we can, or could, manipulate and what we cannot. However, von Wright makes it clear that he is not aiming at any anthropocentric metaphysics of causation, even though he maintains that "to think of a relation between events as causal is to think of it under the aspect of (possible) action" (von Wright 1971: 74). This is only a matter of how we must think, or how we (must) organize our concepts; it does not mean that there is any genuine agency involved in causation (ibid.: 73). Causation, after all, "operates throughout the universe - also in spatial and temporal regions forever inaccessible to man" (ibid.). Von Wright (1974: 48-50) makes this more precise by saying that while causation is conceptually dependent on agency, it is "ontically independent of agency" (ibid.: 49). The "conceptual" dependence lies between "the notion of a (causal) counterfactual conditional and action," instead of lying directly between cause and action (ibid.: 50). Thus, in brief, "the concept of causal connection rests on the concept of action" ( ibid.: 53). In any event, this conceptual link does connect von Wright's views with pragmatism: our world-picture generally, including our conception of causal relations in particular, must be thought of in terms of, or on the basis of, our conception of our own agency. ${ }^{18}$

The second pragmatist aspect of von Wright's views I want to highlight emerges from the fact that, while causation must be thought of in terms of, or "under the aspect of," possible action, human actions cannot, according to von Wright, be simply causally explained. To attempt to do so would be to commit a kind of category mistake. Von Wright's $(1971,1980,1998)$ "non-causalist" conception of action, agency, and freedom and their proper explanation - is arguably more relevant in contemporary philosophy of mind and action than has been generally acknowledged by mainstream philosophers in these fields. Von Wright has consistently opposed attempts to reduce intentionality or agency to a causal, natural-scientific picture of the world. ${ }^{19}$ The concept of freedom, in particular, cannot be accommodated in such a picture. Denying that agents are free would be "to commit a contradiction in terms," while the "mystery" of human freedom is nothing more than the "mystery" that "there are agents and actions" (von Wright 1980: 77-8). Freedom, then, is a fully non-mysterious feature of agency based on our ability to understand human beings as persons and to rationally explain their actions on that basis. No non-natural causal connections between the mental and the physical are presupposed, because intentions are reasons, not causes; there is no need to postulate such Cartesianlike interactionist causation, according to von Wright (1998: 109). As Rosaria Egidi (2009) emphasizes, von Wright shares with Deweyan pragmatism the reconciliatory desire to develop a worldview rich enough for both human agency and natural science - a "naturalistic humanism." 20 


\section{Antireductionism and the Disunity of Science} explanation but also at a metaphilosophical level. He defends a conceptual and explanatory pluralism according to which our different levels of inquiry and explanation, or different perspectives of description and conceptualization (i.e., the neural, the behavioural, and the mental or psychological), each have their own roles to play in our overall understanding of human experience and action. These different schemes, "vocabularies" (as a Rortyan pragmatist would prefer to put it), or language-games (in Wittgensteinian terms) are each legitimate for their own purposes - just like the two essentially different modes of explanation, the causal and the intentional (teleological), investigated in von Wright's seminal work on explanation and understanding (von Wright 1971). When explaining any event taking place in the world, we must always explain it under some description, first conceptualizing and thereby understanding it either as a natural event to be causally explained or as a human action with meaning, to be intentionally, rationally, and hence teleologically explained. In this sense, explanation - and even the notion of causation insofar as it is involved in causal explanations, in contrast to intentional or teleological explanations - is interest-relative (as is, of course, intentionality or teleology, as well).

At this point, we might, in addition to von Wright's pragmatism, even speak about his fundamental Kantianism. Just like Kant sought to reconcile the "worlds" of causally determined nature, on the one hand, and human action and moral responsibility, on the other, von Wright investigates the pragmatic interest-relativity of different explanations of the "same" world under different aspects. Furthermore, if the same compatibility of nature and freedom - determinism and moral responsibility - is also a pragmatist theme, Kantianism and pragmatism seem to converge on this key issue.

idea becomes extremely important in von Wright's late work on the philosophy of mind (von Wright 1998), which is less generally known and appreciated among philosophers today than his action-theoretical investigations from the 1960s and 1970s. ${ }^{21}$ Von Wright's antireductionism and his resistance to any reductively naturalist "unity of science" also clearly links him to his teacher Kaila, whose antireductionism was discussed above (see also von Wright 1992). As non-reductive naturalism has been a major theme in pragmatism - arguably all the way from the classical figures Peirce, James, and Dewey to contemporary neopragmatists ${ }^{22}$ - these two Finnish philosophers' ways of developing similar ideas make them original contributors to a stream of thought at least analogous to pragmatism if not pragmatist properly speaking.

The difference to pragmatism proper, however, is that the different schemes, vocabularies, or language-games that von Wright distinguishes and whose irreducibility he defends are not all ontologically relevant in the same way. While rational (intentional) explanations of actions, referring to reasons instead of causes (von Wright 1998: 19-20, 38-9), can be said to be epistemically prior to behavioral and neural explanations, because mental (psychological) states are epistemically prior to neural (physiological) states, and while behavior in turn can be regarded as semantically prior to mental states, because the content of mental states is available only through observations of outward actions, ${ }^{23}$ neural processes within the organism are, von Wright admits, causally prior to behavior. In a nutshell, an action, according to von Wright, is a bodily movement "viewed under the

European Journal of Pragmatism and American Philosophy, XI-1 | 2019 
aspect of intentionality" (ibid.: 142); the muscular activity and the action share the same " robust reality" while being differently described and conceptualized (ibid.: 34-5). Thus, there is a sense in which the neural or neuro-physiological processes giving rise to certain behavior are ontologically fundamental in comparison to everything else in human action and agency. The pluralism of relevant conceptualizations and explanations is not to be conflated with ontological pluralism.

This is a key contrast to, say, Hilary Putnam's $(1995,2002)$ conceptual relativity and pragmatic pluralism - or to James's (1975 [1907]) pluralistic constructivism, according to which objects themselves arise out of human purposive practices. ${ }^{24}$ I would be tempted to add that this is also a somewhat non-Wittgensteinian dimension in von Wright's pragmatic pluralism - despite his profound and long-lasting exposition to Wittgenstein's work. If any ontological or metaphysical inquiry can be said to be possible or acceptable in Wittgenstein's philosophy at all, Wittgenstein would presumably resist the conclusion (or, rather, assumption) that some schemes, vocabularies, perspectives, or languagegames are ontologically serious while some others are not (though in this paper I won't make any detailed comments on the Finnish pragmatists' relations to Wittgenstein, as important as those relations are). The very distinction von Wright relies on in his theory of causation, that is, the distinction between, as we may say, the ontological order of the world and the conceptual order of our ways of thinking about the world - a distinction crucially manifested in his contention that while the concept of causation presupposes the concept of agency, causation itself, as operative throughout nature, is independent of actions and agents - is, for a pragmatist, precisely the problematic starting-point of metaphysical realism that leads to philosophical difficulties. Both classical pragmatists like James (and even Peirce and Dewey, suitably interpreted) and neopragmatists like Putnam would argue, in opposition to this distinction, that we can have access only to a world that we have conceptualized from the perspectives of our practice-embedded categorial (categorizing) frameworks or language-games. Hence, the distinction between ontic (ontological) and epistemic (conceptual) conclusions regarding indeterminism to be drawn from von Wright's (1974) application of the theory of causation to the determinism vs. indeterminism issue might also be argued to be problematic from a pragmatist perspective (cf. again, e.g., Pihlström 2009).

Even so, von Wright in his late work arrived at a position denying the unity of the scientific worldview - maintaining that there is an irreducible plurality in our descriptions and explanations of reality in the sense sketched above - and this endorsement of the "disunity" of science may be seen as a truly pragmatist theme in his work. At least von Wright joins the pragmatists, classical and contemporary, in resisting any reductive physicalism about human action and culture. ${ }^{25} \mathrm{He}$ also joints his teacher Kaila in developing an (admittedly very different) combination of non-reductive naturalism and pragmatist humanism.

There is, furthermore, one interesting remark in von Wright's Wittgenstein, in his essay on Wittgenstein's views on certainty, that connects von Wright's interpretation of Wittgenstein with his theory of action and explanation. Having examined at some length On Certainty and Wittgenstein's (1969) conception of the "non-propositional" or "prepropositional" - hence pragmatic - character of the "world-picture" and forms of life underlying our language (cf. also, e.g., Pihlström 2003a), he observes: "But in order that my behaviour should be describable as actions of a certain kind, it must be interpreted in terms of the notions of the language-game itself. So, to this extent the praxis at the basis 
of the language-game is a pre-praxis, one could say, and not yet a full-fledged action." (Von Wright 1982: 179).

This is a profound remark. We too easily speak about action lying at the basis of our language-games, or about "deed" being "in the beginning." Wittgenstein himself says things of this kind. But actions properly speaking are something that are always already conceptualized - they have reasons. They can be conceptualized and understood only within a language-game, or more generally within a meaningful human practice. Hence, the "action" that incorporates and manifests our most fundamental (albeit revisable) certainties - the action constituting our "hinges" - cannot really be action in this sense. The non-propositional hinges enabling language-games and meanings are not themselves meaningful; in the same sense, the actions manifesting those hinges are not proper actions. In this pre-praxis, we might say, we follow rules blindly and our "spade is turned" (cf. Wittgenstein 1953: I, §§ 217, 219).

To take a von-Wrightian example: it belongs to my "pre-praxis," to my fundamental certainties ("hinges"), that I do not first make sure that I still have my two hands before engaging in the proper "praxis" or action of opening the window (manifested in certain kind of outward behavior) with the intention of cooling the room. However, the pragmatist insisting on beliefs and other propositional states being "habits of action" might resist this division of human behaviors into proper actions and (a kind of) pseudoactions, or the corresponding division of our activities into proper praxis and pre-praxis. There is, arguably, a continuity here instead of any sharp separation reflecting an essentialistic difference. The very notion of a habit of action can be employed to highlight this continuity. ${ }^{26}$

\section{Concluding Remarks: Kaila and von Wright as $P$ ublic Philosophers}

41 The fourth dimension of von Wright's so-called pragmatism is presumably better known to his Finnish and Scandinavian colleagues and followers than to his international academic audience. In his home country Finland, he was a widely respected "public philosopher" in a manner perhaps comparable to, say, Dewey in the United States or even Jean-Paul Sartre in France. Probably his best known work in this area is Vetenskapen och förnuftet (Science and Reason, 1986), which criticizes the self-destructive tendencies of Western civilization, particularly the way in which human reason itself, through its scientific and technological advances and applications, has driven the world close to ecological destruction. ${ }^{27} \mathrm{Had}$ he lived to witness the growing worries about the global climate change in the 2000s, he might have ended up even more pessimistic than he was in his old days.

Clearly, a pragmatist thinker may be expected to be active in public issues such as environmental problems, social policy, or war and peace. In contrast to many pragmatists' (especially Dewey's) progressivism and optimism, von Wright as a publically well-known figure commenting on deep issues facing our human civilization shared the cultural pessimism of figures like Wittgenstein and Oswald Spengler. Neither Wittgenstein nor von Wright felt completely "at home" in the world and culture they lived in. Thus, again, he was not a pragmatist properly speaking while developing a pragmatic way of doing philosophy as cultural criticism. The kind of profile as a public 
philosopher that Kaila had was somewhat different - and closer to that of someone like James. For Kaila, public engagements by philosophers were essential (or so it seems) primarily because the kind of "ultimate questions" he dealt with in Syvähenkinen elämä deserved to be discussed in a generally accessible way; while Kaila himself was an aristocratic elitist, he seems to have felt that his general readers and listeners had a right to find deeper layers of meaning in their lives, and that he could offer something like philosophical guidance in this respect.

Von Wright's and Kaila's cases demonstrate that one can be a pragmatist in many different ways. Here we may see pragmatic contextuality and (Wittgensteinian) family resemblance at work. One can be a pragmatist in "first-order" issues but also in "secondorder" or meta-level ones, or both. There is very little we find in von Wright's thought that can be directly linked with pragmatism, but at the meta-level there is, in fact, a lot.

To sum up, we may say that Kaila was a logical empiricist and, perhaps, a quasipragmatist with explicit Jamesian influences, while von Wright was never really influenced or even very much inspired by any of the old pragmatists. He was, thus, an original "European pragmatist" in the sense that his pragmatic view of causation was truly his own innovation, not derived from any of the pragmatist classics (unlike, it seems, Kaila's idea of practical testability, which can to a certain degree be traced back to James). As a quasi-pragmatist, von Wright was, then, more independent, but both were equally independent as central figures of Finnish and European philosophy throughout the twentieth century.

Kaila's and von Wright's pupils and followers developed their own versions of pragmatic humanism - or so, at least, we may interpret Oiva Ketonen's work on naturalism in a broadly Deweyan context, and possibly even Ilkka Niiniluoto's critical scientific realism, which is to a large extent based on Peircean ideas of scientific progress, while maintaining a humanistic acknowledgment of the autonomy of philosophy and its irreducibility to empirical science..$^{28}$ On the other hand, Jaakko Hintikka's relation to this tradition (if it can be called by that name) seems to be much more complicated. ${ }^{29}$ In a way or another, all these Finnish thinkers have engaged in a critical dialogue with the program of naturalism and naturalization in analytic and post-analytic philosophy. In this sense, too, their projects resemble the classical pragmatists' and are also central background views for those of us (in Finland and elsewhere) working on the history of pragmatism.

\section{BIBLIOGRAPHY}

APEL Karl-Otto, (1988), From a Transcendental-Semiotic Point of View, Manchester, Manchester University Press.

CalCATERra Rosa M., (1999), “W. James' Defence of Free Will: A Step toward a Paradigm Shift," in Egidi Rosaria (ed.), In Search of a New Humanism: The Philosophy of Georg Henrik von Wright, Dordrecht, Kluwer, 139-46. 
EGIDI Rosaria (ed.), (1999), In Search of a New Humanism: The Philosophy of Georg Henrik von Wright, Dordrecht, Kluwer.

EGIDI Rosaria, (1999), “Von Wright and 'Dante's Dream': Stages in a Philosophical Pilgrim's Progress," in Id. (ed.), In Search of a New Humanism: The Philosophy of Georg Henrik von Wright, Dordrecht, Kluwer, 1-34.

EGIDI Rosaria, (2009), “Von Wright's Philosophical Humanism," European Journal of Pragmatism and American Philosophy, 1 (1), 1-8. Online: [journals.openedition.org/ejpap/973].

HARTSHORNE Charles, (1989), "Von Wright and Hume's Axiom," in Paul Arthur Schilpp \& Lewis Edwin Hahn (eds), The Philosophy of Georg Henrik von Wright, La Salle, IL, Open Court, 59-76. HINTIKKA Jaakko, (1998), “What Is Abduction? The Fundamental Problem of Contemporary Epistemology," Transactions of the Charles S. Peirce Society, 34, 503-33.

JÄÄSKELÄINEN Manu, (1983), Eino Kailan psykologia: Rakenne ja kehitys. Käsiteanalyyttinen tutkimus [Eino Kaila's Psychology - Its Structure and Development. A Conceptual Analysis], Helsinki, Department of Psychology, University of Helsinki.

JAMES William, (1975 [1907]), Pragmatism: A New Name for Some Old Ways of Thinking, eds. Frederick H. Burkhardt, Fredson Bowers, \& Ignas K. Skrupskelis, Cambridge, MA and London, Harvard University Press.

JAMES William, (1979 [1897]), The Will to Believe and Other Essays in Popular Philosophy, eds. Frederick H. Burkhardt, Fredson Bowers \& Ignas K. Skrupskelis, Cambridge, MA and London, Harvard University Press.

KAILA Eino, (1911a), “Nykyajan filosofeja. Henri Bergson” [Contemporary Philosophers. Henri Bergson], in Valitut teokset 1: 1910-1935 [Selected Works 1: 1910-1935], ed. Ilkka Niiniluoto, Helsinki, Otava, 43-58 (abridged).

KAILA Eino, (1911b), “Tiede ja todellisuus. Lausuntoja Bolognan filosofikongressista” [Science and Reality. Statements about the Philosophy Congress in Bologna], Aika, 5, 761-4.

KAILA Eino, (1912), “William James. Amerikan filosofi” [William James. The Philosopher of America], in Valitut teokset 1: 1910-1935 [Selected Works 1: 1910-1935], ed. Ilkka Niiniluoto, Helsinki, Otava, 80-92. (English translation by Heikki A. Kovalainen, (2011), in Transactions of the Charles S. Peirce Society, 47, 136-45.)

KAILA Eino, (1914), Review of William James, Pragmatismi (1913) [the Finnish translation of Pragmatism], Uusi Suometar, April 7, 1914. (Finnish National Library, microfilm 214.)

KAILA Eino, (1915), Review of William James, Uskonnollinen kokemus moninaisuudessaan (1914) [the Finnish translation of The Varieties of Religious Experience], Uusi Suometar, March 9, 1915. (Finnish National Library, microfilm 219.)

KAILA Eino, (1916), Review of William James, Elämän ihanteita (1916) [Finnish translation of Talks to Teachers], Uusi Suometar, May 20, 1916. (Finnish National Library, microfilm 224.)

KAILA Eino, (1917), Renan [in Finnish], Porvoo, WSOY. (Abridged in Kaila 1990.)

KAILA Eino, (1941-48), Unpublished diaries, Suomalaisen Kirjallisuuden Seura (Finnish Literature Society), archives, Helsinki (No. 22230).

KAILA Eino, (1946 [1934]), Persoonallisuus [Personality], Helsinki, Otava, 3rd ed. (Abridged in Kaila 1990.) 
KAILA Eino, (1952), “Allt är materia, allt är själ” [Everything Is Matter, Everything Is Soul], in Id. (1992), Valitut teokset 2: 1936-1958 [Selected Works 2: 1936-1958], ed. Ilkka Niiniluoto, Helsinki, Otava.

KAILA Eino, (1953), "Laatujen asema suureiden maailmassa" [The Place of Qualities in a World of Quantities], in Id. (1992), Valitut teokset 2: 1936-1958 [Selected Works 2: 1936-1958], ed. Ilkka Niiniluoto, Helsinki, Otava.

KAILA Eino, (1979), Reality and Experience: Four Philosophical Essays, ed. Robert S. Cohen, Dordrecht, D. Reidel.

KAILA Eino, (1986 [1943]), Syvähenkinen elämä: Keskusteluja viimeisistä kysymyksistä [Deep-Mental Life: Dialogues concerning Ultimate Questions], Helsinki, Otava, 3rd ed. (Abridged in Kaila 1992.) KAILA Eino, (1990), Valitut teokset 1: 1910-1935 [Selected Works 1: 1910-1935], ed. I. Niiniluoto, Helsinki, Otava.

KAILA Eino, (1992), Valitut teokset 2: 1936-1958 [Selected Works 2: 1936-1958], ed. I. Niiniluoto, Helsinki, Otava.

KAILA Eino, (2014 [1939]), Human Knowledge: A Classic Statement of Logical Empiricism, trans. Anssi Korhonen; eds. Juha Manninen, Ilkka Niiniluoto, and George A. Reisch, La Salle, IL, Open Court. KeTONEN Oiva, (1954), “John Dewey 1859-1952” [in Finnish], Ajatus, 18, 85-98.

KETONEN Oiva, (1981 [1961]), Eurooppalaisen ihmisen maailmankatsomus [The World-View of the European Man], Porvoo, WSOY, 3rd ed.

KUUSELA Antti, (2010), Non-reductive Physicalism, Irreducibility of the Mental and the Problem of Mental Causation: A Study of Donald Davidson's and Georg Henrik von Wright's Positions in the Philosophy of Mind , PhD Diss., Department of Philosophy, University of Helsinki, available online: [doria.fi/ handle/10024/64338].

NEUBER Matthias, (2012), "From Carnap to Kaila - A Neglected Transition in the History of " wissenschaftliche Philosophie'," in Niiniluoto \& Pihlström, Reappraisals of Eino Kaila's Philosophy, Acta Philosophica Fennica 89, Helsinki, The Philosophical Society of Finland, 53-70.

NiINILUoTo Ilkka, (1990), “Luonto, elämä ja sielu: Eino Kaila 1910-35” [Nature, Life, and Soul: Eino Kaila 1910-35], in Kaila 1990, 9-38.

NIINILUOTо Ilkka, (1992a), “Syvähenkisen empiristin hahmottuva maailma: Eino Kaila 1936-58” [The Structuring World of the Deep-Mental Empiricist: Eino Kaila 1936-58], in Kaila 1992, 7-33. NiINILUoto Ilkka, (1992b), “Eino Kaila and Scientific Realism,” in Niiniluoto et al. 1992, 102-16. NiIniluoto Ilkka, (1999), Critical Scientific Realism, Oxford and New York, Oxford University Press. Niniluoto Ilkka, (2012), “Eino Kaila's Critique of Metaphysics," in Niiniluoto \& Pihlström, Reappraisals of Eino Kaila's Philosophy, Acta Philosophica Fennica, 89, Helsinki, The Philosophical Society of Finland, 71-90.

Niniluoto Ilkka, (2017), "Eino Kaila and The Vienna Circle," in Sami Pihlström, Friedrich Stadler, \& Niels Weidtmann (eds), Logical Empiricism and Pragmatism, Vienna Circle Institute Yearbook 19, Cham, Springer, 185-99.

NIINILUото Ilkka, (2018), Truth-seeking by Abduction, Cham, Springer.

NIINILUoto Ilkka, sintonEn Matti \& Georg Henrik von WRIGHT (eds), (1992), Eino Kaila and Logical Empiricism, Acta Philosophica Fennica 52, Helsinki, The Philosophical Society of Finland. 
NIINILUOTO Ilkka \& Sami PIHLSTRÖM (eds), (2012), Reappraisals of Eino Kaila's Philosophy, Acta Philosophica Fennica, 89, Helsinki, The Philosophical Society of Finland.

NiINILUOTo Ilkka \& Thomas WALLGREN (eds), (2017), On the Human Condition: Philosophical Essays in Honour of the Centennial Anniversary of Georg Henrik von Wright, Acta Philosophica Fennica, 93, Helsinki, The Philosophical Society of Finland.

PIHLSTRÖM Sami, (2001), Filosofin käytännöt: Pragmatismin perinteen vaikutus suomalaisessa filosofiassa 1900-luvulla [The Philosopher's Practices: The Influence of the Pragmatist Tradition in Finnish Philosophy in the Twentieth Century], Kuopio, UNIPress.

PIHLSTRÖM Sami, (2003a), Naturalizing the Transcendental: A Pragmatic View, Amherst, NY, Prometheus/Humanity Books.

PIHLSTRÖM Sami, (2003b), "Pragmatistic Influences in Twentieth Century Finnish Philosophy: From Pre-Analytic to Post-Analytic Thought," in Leila Haaparanta \& Ilkka Niiniluoto (eds), Analytic Philosophy in Finland (Poznan Studies in the Philosophy of the Sciences and the Humanities 80), Rodopi, Amsterdam and New York, 511-35.

PIHLSTRÖM Sami, (2009), Pragmatist Metaphysics: An Essay on the Ethical Grounds of Ontology, London and New York, Continuum.

PIHLSTRÖM Sami, (2010), "Nordic Pragmatism," European Journal of Pragmatism and American Philosophy, 2 (1), available online: [journals.openedition.org/ejpap/945]. (Earlier version in Sami Pihlström \& Henrik Rydenfelt (eds), Pragmatist Perspectives, Acta Philosophica Fennica 86, The Philosophical Society of Finland, Helsinki, 2009: 11-25.)

PIHLSTRÖM Sami, (2012), “Eino Kaila on Pragmatism and Religion," in Niiniluoto \& Pihlström 2012, 195-212.

PIHLSTRÖM Sami, (2014), “A Pragmatist Dimension in Georg Henrik von Wright's Philosophy,” Acta Baltica Historiae et Philosophiae Scientiarum, 2 (1), 5-17.

PIHLSTRÖM Sami (ed.), (2015), The Bloomsbury Companion to Pragmatism, New York and London, Bloomsbury.

PRICE Huw, (2011), Naturalism without Mirrors, Oxford and New York, Oxford University Press.

PUTNAM Hilary, (1995), Pragmatism: An Open Question, Oxford and Cambridge, MA, Blackwell.

PUTNAM Hilary, (2002), The Collapse of the Fact/Value Dichotomy and Other Essays, Cambridge, MA and London, Harvard University Press.

RYDENFELT Henrik, (2018), "Nordic Context," in Matthias Festl (ed.), Handbuch Pragmatismus, Stuttgart, Metzler, 321-6.

SALMELA Mikko, (1998), Suomalaisen kulttuurifilosofian vuosisata [A Century of Finnish Philosophy of Culture], Helsinki, Otava.

SAlMElA Mikko, (2012), “Eino Kaila on Ethics,” in Niiniluoto \& Pihlström 2012, 213-32.

SCHILPP Paul Arthur \& Lewis Edwin HAHN (eds), (1989), The Philosophy of Georg Henrik von Wright, La Salle, IL, Open Court.

WITTGENSTEIN Ludwig, (1953), Philosophical Investigations, trans. G. E. M. Anscombe, Oxford, Basil Blackwell, 1958.

WitTGenstein Ludwig, (1969), On Certainty, eds. G. E. M. Anscombe and G. H. von Wright, trans. G. E. M. Anscombe and Denis Paul, Oxford, Basil Blackwell. 
WOODWARD James, (2003), Making Things Happen: A Theory of Causal Explanation, Oxford, Oxford University Press.

VON WRIGHT Georg Henrik, (1943), Den logiska empirismen: En huvudriktning i modern filosofi [Logical Empiricism: A Main Orientation in Modern Philosophy], Helsingfors, Söderströms.

VON WRIGHT Georg Henrik, (1971), Explanation and Understanding, Ithaca, NY and London, Cornell University Press.

VON WRIGHT Georg Henrik, (1974), Causality and Determinism, New York and London, Columbia University Press.

VON WRIGHT Georg Henrik, (1980), Freedom and Determination, Acta Philosophica Fennica, 31 (1), Helsinki, The Philosophical Society of Finland.

VON WRIGHT Georg Henrik, (1982), Wittgenstein, Oxford, Basil Blackwell.

VON WRIGHT Georg Henrik, (1986), Vetenskapen och förnuftet [Science and Human Reason], Finnish trans. Anto Leikola, Tiede ja ihmisjärki, Helsinki, Otava, (1987).

VON WRIGHT Georg Henrik, (1992), “Eino Kaila's Monism,” in Niiniluoto et al. 1992, 71-91.

VON WRIGHT Georg Henrik, (1993), The Tree of Knowledge, Leiden, Brill.

VON WRIGHT Georg Henrik, (1998), In the Shadow of Descartes: Essays in the Philosophy of Mind, Dordrecht, Kluwer.

VON WRIGHT Georg Henrik, (2001), Elämäni niin kuin sen muistan [My Life as I Remember It], trans. Iiro Kuuranne, Helsinki, Otava.

WALLGREN Thomas, (2003), "Critical Theory," in Leila Haaparanta \& Ilkka Niiniluoto (eds), Analytic Philosophy in Finland. Poznan Studies in the Philosophy of the Sciences and the Humanities, 80, Amsterdam, Rhodopi, 537-79.

\section{NOTES}

1. The topic of this paper has been more comprehensively discussed in several earlier writings of mine: see Pihlström 2001, 2003b, 2010, 2012, 2014; see also Pihlström 2015. This essay is indebted to those previous investigations of "Finnish pragmatism."

2. Hintikka's relation to pragmatism would clearly deserve a separate comprehensive study. In particular, his research on Peirce and abduction is an original contribution to the development of the specifically Peircean strand of pragmatism (as is Niiniluoto's work on abduction; cf. Niiniluoto 2018). It might be mentioned that Hintikka was President of the Charles S. Peirce Society in the 1990s.

3. In addition to his early articles on James, he also published a brief monograph in Finnish on Ernest Renan's work on religion (Kaila 1917), dealing with related matters. Kaila's most important writings, including some of the early pieces of the 1910s (e.g., the James article and selections of the Renan book), are collected in Kaila 1990. The writings on Renan, James, and other figures testify about Kaila's deep interest in religious issues and the conflict between science and religion.

4. I am here quoting from Heikki A. Kovalainen's 2011 translation of Kaila 1912, though otherwise my page references are to the reprinted version of the original Finnish essay available in Kaila 1990. The last sentence in the quotation seems to have been taken almost directly from James's essay, "What Makes Life Worth Living," reprinted in James 1979 [1897]. 
5. Niiniluoto, in his introduction to Niiniluoto et al. 1992, uses this as a translation of Kaila's most original terminus technicus, "syvähenkisyys." This concept has been discussed in Jääskeläinen 1983, Niiniluoto 1992a, and Salmela 1998, among other secondary sources. See also the essays in Niiniluoto \& Pihlström 2012.

6. It is, however, still an open question whether we should say that what Kaila thought to be pragmatically acceptable or justifiable could be regarded as (pragmatically) "true." Kaila clearly does not follow the pragmatists all the way down, because he still insists on distinguishing between theoretical and practical testability (and truth). Furthermore, Salmela $(1998,2012)$ claims that Kaila's principle of practical testability is applicable only to religion and metaphysics, not to value judgments. There is still room for further scholarly discussion of Kaila's metaethical position: did he subscribe to some kind of emotivism, or are his treatments of deep-mentality reinterpretable on the basis of a pragmatic moral realism? For a detailed account of Kaila's relation to other twentieth-century Finnish developments in the philosophy of culture and values, see Salmela 1998.

7. Kaila does regard James (along with Carlyle and Tolstoy) as one of the background figures of Aristofilos's feelings about life (see Kaila 1986 [1943]: 8, 202). Kaila's diaries in 1941-48 indicate that he was thinking about James while preparing the manuscript of Syvähenkinen elämä during World War II. He mentions James at least on December 13, 1941, and on May 4, 1942. On January 24,1943 , he formulates the distinction between theoretical and practical testability.

8. On the notion of a philosophical temperament, see James 1975 [1907], Lecture I.

9. On Kaila's life-long concern with the issue of scientific realism and the "riddle of reality" in the context of the logical empiricists' criticism of metaphysics, see Niiniluoto 1992b, 2012, 2017; cf. also Neuber 2012.

10. See von Wright 1992 for some elaborations of this.

11. Kaila's last work, only fragments of which were posthumously published, was tentatively titled Hahmottuva maailma ("The World as a Structuring Whole," or perhaps just "The Structuring World," or maybe "The Self-Structuring World"). For English translations of some material that Kaila intended as part of that volume, see Kaila 1979, especially the essay "The Perceptual and Conceptual Components of Everyday Experience" (259-312).

12. Compare James's own discussion of monism and pluralism in James 1975 [1907], Lecture IV. While James obviously favors pluralism, even that conflict is for him an issue that needs pragmatic adjudication.

13. This 1952 paper is reprinted in Kaila 1992.

14. Again, see the elaboration of this idea in Kaila's posthumous essay, "The Perceptual and Conceptual Components of Everyday Experience," in Kaila 1979. See also Niiniluoto (1992b: 111).

15. This is suggested, with some reservations, in Niiniluoto (1992b: 112-3). I agree with Matthias Neuber (2012) that Kaila cannot be interpreted as an internal realist in the Putnamian sense, because he never accepted the Kantian view that reality is dependent on our conceptualizations and categorizations. (This Kantian idea is in my view crucial in pragmatist and neopragmatist ways of dealing with the problem of realism. I would also be happy to agree with Neuber that Putnamian internal realism, at least insofar as it is a pragmatist position, is indeed very close to Kantian-like idealism.) Even so, the link between conceptualization and reality is tight in Kaila.

16. The Library of Living Philosophers volume devoted to von Wright (Schilpp \& Hahn 1989) does not seem to recognize von Wright's pragmatist aspects in any explicit way. See, however, Hartshorne 1989.

17. Huw Price's work on causation might be seen as coming close to von Wright's, because Price (2011: 31) also suggests that "uses of causal concepts in science" may reflect the "agentive perspective."

18. Regarding this deep connection between the ways we talk and think about the world generally and the ways we talk and think about human agency, it might be speculated that von 
Wright's later views on the conceptual dependence of causation on action might be partly based on, or at least parallel to, his earlier idea - originated during his Cambridge years (1948-1951), leading up to his pioneering work on modal and deontic logic, with the first publications in the early 1950s - that there is an analogy between the behaviors of the standard quantifiers of firstorder predicate logic, on the one hand, and the operators expressing modalities and deontic modalities, on the other. Thus, our basic logical concepts "some," "all," and "no" can be seen as functioning in ways analogous to modal concepts ("possible," "necessary," and "impossible") and deontic ones ("allowed," "obligated," "forbidden"). Von Wright (2001: 179) tells us that this analogy came to him as a sudden insight when he was walking along the river Cam (presumably around 1950).

19. On the relevance of von Wright's "actionistic" account of causation for an "anti-naturalistic" "humanization of nature," see Egidi (1999: 4-5). Similarly, pragmatists are generally naturalists, but their naturalism is never reductive but always already "humanized" - and the same, as we saw, holds for von Wright's teacher Kaila. Calcaterra (1999) is one of the very few scholars explicitly comparing von Wright's theory of action and (James's) pragmatism, pointing toward a "non-causalistic" theory of action and an "emancipation of the discussion about human freedom from traditional epistemological and ontological approaches" (ibid.: 139). See Egidi’s (1999, ed.) volume more broadly for several investigations of von Wright's views on action (among other things) and their significance for "humanistic" philosophy.

20. As von Wright explains in his autobiography (von Wright 2001), he later came to resist the term "humanism," though. For more recent discussions of von Wright's humanism and his views on "the human condition," see Niiniluoto \& Wallgren 2017.

21. I am here indebted to Antti Kuusela's (2010) work on von Wright's philosophy of mind, with comparisons to not only Wittgenstein but also Donald Davidson.

22. Dewey, of course, contributed to the logical empiricists' International Encyclopedia of Unified Science with his Theory of Valuation in 1940 and was in this sense not exactly a critic of the "unity of science" movement but rather one of its supporters. On the other hand, Dewey's version of pragmatic naturalism is clearly one of the most influential accounts of non-reductive naturalism available. It would require another inquiry to determine in what sense exactly a non-reductive (and in this sense "rich" or "soft") version of naturalism can be committed to the idea of "unity" (i.e., in what sense, if any, unity itself can be reconstructed in a non-reductive manner).

23. The mental, von Wright (1998: 162) tells us, is "the meaning of complex patterns of bodily reactions."

24. See also Pihlström 2009 for some developments of these versions of pragmatism.

25. Von Wright's view on causation has also inspired, among others, Karl-Otto Apel (cf. Apel 1998: 22-3, 133). The "interventionist" position has been important for Apel as a background idea in his defense of critical hermeneutics and "transcendental pragmatism" in the Erklären vs. Verstehen controversy (see also Wallgren 2003: 543).

26. The issue of continuity is also related to the question concerning the possible intentionality (or lack thereof) of the actions or behaviors of higher animals. Is there an evolutionary continuity here or a fundamental difference between our intentional actions and the purely causally explainable non-intentional (though possibly intentional-seeming) behavior of animals? I must here leave this question untouched, but I should like to note that the difference between those who find human beings essentially different from animals in this regard and those who find them not essentially different but only very different - that is, see them continuous yet very far from each other regarding capacities for reasoned action - may itself be a problematic distinction, or even a distinction without (pragmatic) difference. The pragmatic method could perhaps be employed here in order to show that there is no conceivable difference in the potential practical effects of these only apparently different views. I imagine that this issue could be interestingly investigated in the context of Kaila's and von Wright's ideas, too. 
27. Some of von Wright's "cultural" writings of this kind have been translated into English: see von Wright 1993. Here I am not even trying to summarize his profound views on "the myth of progress," the self-destructiveness of human reason, and cultural pessimism. Von Wright's career as a cultural discussant did not begin with his politically engaged comments in the 1960s but goes back to his early essays in the 1940s on Dostoevsky and Tolstoy.

28. In their distinctive ways, Ketonen and Niiniluoto have also continued the tradition of "public philosophy." For example, in his popular writings and talks, Niiniluoto has recently been a strong critic of the corruption of the commitment to reason and truth in our "post-truth" era.

29. I have deliberately avoided discussing any of Hintikka's complex views here, as his relations to pragmatism would deserve a separate analysis (cf., e.g., Hintikka 1998, as well as footnote 2 above). He was obviously greatly influenced by both Kaila and especially von Wright.

\section{ABSTRACTS}

This essay introduces two leading Finnish philosophers of the twentieth century, Eino Kaila and Georg Henrik von Wright, who not only established analytic philosophy in Finland but also made original contributions to the development of pragmatism. The pragmatist dimensions of Kaila's thought were clearly influenced by the classical American pragmatists, primarily William James, whose writings Kaila read and commented on already at an early stage of his career in the 1910s. Kaila then continued to develop a quasi-pragmatist idea of "practical testability" during his logical empiricist period in the 1930s and 1940s. Unlike Kaila, von Wright was never directly inspired by James or any other classical pragmatists, although he did refer to Peirce and James as informal precursors of logical empiricism in the 1940s. His highly original theories of human action and causation, mostly developed in the 1970s, contain interesting pragmatist aspects, however. Both Kaila and von Wright, moreover, shared a life-long engagement with an issue that also troubled all the classical pragmatists: a reconciliation of a "humanist" philosophy with a thoroughgoing appreciation of the natural sciences. Thus, they both developed non-reductive versions of naturalism (or naturalist versions of pragmatist humanism) that, in their emphasis on the disunity of science, were not terribly far from the positions of classical pragmatists like James and Dewey.

\section{AUTHOR}

\section{SAMI PIHLSTRÖM}

University of Helsinki

sami.pihlstrom[at]helsinki.fi 